Check for updates

Cite this: RSC Adv., 2017, 7, 40533

Received 1st June 2017

Accepted 10th August 2017

DOI: 10.1039/c7ra06105f

rsc.li/rsc-advances

\title{
Deep-red organic light-emitting diodes with stable electroluminescent spectra based on zinc complex host material
}

\author{
Yungui Li, (iD ${ }^{a}$ Xiang Gao, (D) ${ }^{b}$ Lei Wang (DD ${ }^{a}$ and Guoli Tu*a
}

A zinc complex host material named $\mathrm{Zn}(\mathrm{PPI})_{2}$ (PPI = 2-(1-phenyl-1H-phenanthro[9,10-d]imidazol-2-yl) phenol) is synthesized by an improved strategy. Combined with dopant $\operatorname{Ir}(\text { piq })_{3}$ and $\operatorname{Ir}(\text { pmiq })_{2}($ acac), deepred phosphorescent organic light-emitting diodes are fabricated and investigated. The devices show a highest external quantum efficiency of $9.5 \%$ based on $\operatorname{Ir}(\text { piq })_{3}$ and $13.1 \%$ for $\operatorname{Ir}(\text { pmiq })_{2}($ acac $)$. All these devices show very stable electroluminescent spectra without significant shift during current density increase. Commission Internationale de l'Eclairage coordinates of $(0.68,0.32)$ and $(0.70,0.30)$ are obtained respectively.

\section{Introduction}

Organic light-emitting diodes (OLEDs) have gained significant attention after their invention by Tang and Vanslyke in $1987 .^{1}$ With the introduction of phosphorescent ${ }^{2,3}$ and thermally activated delayed fluorescent (TADF) emitters, ${ }^{\mathbf{4}, 5}$ the internal quantum efficiency of phosphorescent OLEDs (PhOLEDs) can reach as high as $100 \%$, which indicates unity energy conversion. The development of organic doping technology, ${ }^{6}$ exciton blocking layers ${ }^{7}$ and light extraction strategies ${ }^{8}$ bring white PhOLEDs to a level with comparable with the power efficiency of fluorescent tubes. ${ }^{9}$ After decades of effort, OLEDs have now been used in display panels and light sources.

Increasing interest have been paid to deep-red and nearinfrared OLEDs because of their potential application in fields like phototherapy, $^{\mathbf{1 0}}$ telecommunication $^{\mathbf{1 1}}$ and defense. ${ }^{\mathbf{1 2}}$ However, the external quantum efficiency (EQE) of deep-red OLEDs with Commission Internationale de l'Eclairage (CIE) coordinate CIE $x \geq 0.70$ is still low. What is more, the CIE coordinate under high current density is rarely discussed in previous reports. Under high current density, the shift of recombination zone could lead to blue shift, giving rise to emission with lower CIE $x$ value. ${ }^{13}$

The key issues to obtain an ideal deep-red devices with CIE $x$ $\geq 0.7$ are the emission peak wavelength and the bandwidth of spectrum. ${ }^{\mathbf{1 4}}$ To get emission with a stable CIE coordinate, device needs to have balanced hole and electron injection, and stable recombination zone without significant shift at high current

${ }^{a}$ Wuhan National Laboratory for Optoelectronics, Huazhong University of Science and Technology, Wuhan, P. R. China.E-mail: tgl@hust.edu.cn

${ }^{b}$ School of Materials Science \& Engineering, Hubei Key Laboratory of Plasma Chemistry and Advanced Materials, Wuhan Institute of Technology, Wuhan 430073, China density. To meet these requirements, both material and device configuration should be carefully optimized.

Fujii et al. realized a deep-red OLEDs with EQE of $10.2 \%$ and CIE coordinates of $(0.70,0.27)$, by using a deep-red phosphorescent emitter bis(2,3-diphenylquinoxaline)iridium-(acetylacetone) $\left[(\mathrm{QH})_{2} \operatorname{Ir}(\mathrm{acac})\right]$ and 3-(4-biphenylyl)-4-phenyl-5-(4-tert-butylphenyl)-1,2,4-triazole (TAZ-01) as host. ${ }^{15}$ However, the CIE coordinate shifted to lower than 0.70 when increasing current density. Jou et al. reported a deep-red OLED with [bis(spirofluorenedibenzosuberene $[d]$ quinoxaline- $\left.\mathrm{C}^{2}, N\right)$-monoacetyl-cetone]iridium(III) as emitter and $N, N^{\prime}$-di(naphthalene-1-yl)- $N, N^{\prime}$ diphenylbenzidine (NPD) and bis(10-hydroxybenzo[ $h]$ quinolinato)beryllium $\left(\mathrm{BeBq}_{2}\right)$ as co-host, achieving maximum EQE of $11.2 \%$, and CIE coordinates of $(0.70,0.27)$ at $10 \mathrm{~cd} \mathrm{~m}^{-2} .{ }^{16}$ However, the CIE coordinates moved to $(0.67,0.26)$ when the luminance increased to $500 \mathrm{~cd} \mathrm{~m}^{-2}$. Wang et al. reported a deepred OLED with TADF emitter 7,10-bis(4-(diphenylamino) phenyl)dibenzo[f,h]quinoxaline-2,3-dicarbo-nitrile (TPA-DCPP). Its nondoped OLED device showed maximum EQE of 2.1\% with CIE coordinated of $(0.70,0.29)$. When 20 wt $\%$ TPA-DCPP doped in TPBi as emitting layer, OLED exhibited a maximum EQE of $9.8 \%$ with CIE coordinate of $(0.68,0.32) .{ }^{17}$ Recently, Yuji et al. reported an exciplex system with bis(2,3diphenylquinoxaline)iridium(dipivaloyl-methane) $\quad\left[(\mathrm{DPQ})_{2^{-}}\right.$ $\operatorname{Ir}(\mathrm{dpm})]$ emitter for deep-red OLEDs. Co-deposited di(naphthalene-1-yl)- $N, N^{\prime}$-diphenylbenzidine (NPD) and 2-(3'-(dibenzo $[b, d]$ thiophen-4-yl)-[1,1'-biphenyl]-3-yl)-4,6-diphenyl-1,3,5triazine (4DBT46TRZ) as host, maximum EQE of $17.9 \%$ with CIE coordinates of $(0.70,0.29)$ at $100 \mathrm{~cd} \mathrm{~m}^{-2}$ was obtained. ${ }^{18}$ However, there is no information about CIE coordinate under high current density.

All these host materials were obtained via multi-step synthesis process, which hinders their commercial application because of the synthetic complexity. Adachi et al. reported a zinc complex bis 
[2-(2-benzothiazoyl)phenolato]zinc(II) [Zn(BTP $)_{2}$ ] as host material with $\operatorname{Ir}(\mathrm{piq})_{3}$ dopant for deep-red OLEDs, realizing device performance with maximum EQE of $10.3 \%$. At a current density of $10 \mathrm{~mA} \mathrm{~cm}{ }^{-2}$, CIE coordinate of $(0.67,0.33)$ was obtained. Devices with this zinc complex host material showed higher performance compared to 4,4'-bis(9-carbazolyl)-2,2'-biphenyl (CBP) based devices, but the CIE coordinate at high current density and the color stability were not showed..$^{19}$ According to their research, zinc complex host material $\mathrm{Zn}(\mathrm{BTP})_{2}$ showed better charge carrier injection properties than CBP. Recently, Wang et al. realized blue, green and orange-red devices based on zinc and beryllium complex host with ligand of 2-(1-phenyl- $1 H$-phenanthro[9,10- $d]$ imidazol-2-yl)phenol (PPIH). For organic red PhOLEDs based on $\mathrm{Zn}(\mathrm{PPI})_{2}$ as host material and bis(2-methyldibenzo- $[f, h]$ quinoxaline)acetylac-etonate iridium(III) $\quad\left(\operatorname{Ir}(\mathrm{MDQ})_{2}(\mathrm{acac})\right)$ as dopant, maximum EQE of $15.2 \%$ and CIE coordinate of $(0.64$, $0.36)$ have obtained. The zinc complex host material shows bipolar property of transporting electrons and holes, which facilitates charge balance. However, they used inorganic base sodium hydroxide to synthesize the complex in organic solvent, leading to modest yield (48\%). Low solubility of sodium hydroxide and ligand PPIH in methanol causes difficulty for further purification. ${ }^{20}$ In the interest of simplifying the purification process and increasing product yield, an improved strategy for this zinc complex host is needed. More importantly, there is a lack of investigation on deep-red PhOLEDs and the electroluminescent spectrum stability of those devices with $\mathrm{Zn}(\mathrm{PPI})_{2}$ as host material.

Here, we reported efficient deep-red OLEDs with stable CIE $x$ $\geq 0.7$ based on $\mathrm{Zn}(\mathrm{PPI})_{2}$. An improved synthesis method for $\mathrm{Zn}(\mathrm{PPI})_{2}$ is developed and it is used as a host material for PhOLEDs with dopant $\operatorname{Ir}(\mathrm{piq})_{3}$ and $\operatorname{Ir}(\mathrm{pmiq})_{2}$ (acac), to obtain deep-red OLEDs with CIE $x \geq 0.7$. Rather than using poorly soluble inorganic base sodium hydroxide to adjust $\mathrm{pH}$, we utilize trimethylamine combined with ethanol as solvent to synthesize $\mathrm{Zn}(\mathrm{PPI})_{2}$ complex. The zinc complex material is easily obtained by two steps, with slightly higher product yield of $60 \%$ by simple filter separation. This is among high product yield for zinc complex synthesis. ${ }^{21}$ When this zinc complex is used as host material for deep-red PhOLEDs with $\operatorname{Ir}(\mathrm{piq})_{3}$ emitter, maximum EQE of 9.5\% with CIE coordinate of $(0.68,0.32)$ is achieved. It shows very stable electroluminescent emission, peaking at $636 \mathrm{~nm}$ without significant change of CIE coordinate when increasing current density. The CIE coordinate changes smaller than 0.005 when current density increases from $0.1 \mathrm{~mA} \mathrm{~cm}{ }^{-2}$ to $100 \mathrm{~mA} \mathrm{~cm}{ }^{-2}$. Maximum luminance above $10000 \mathrm{~cd} \mathrm{~m}^{-2}$ is obtained before device failure. Combined with emitter $\operatorname{Ir}(\mathrm{pmiq})_{2}(\mathrm{acac}), \mathrm{Zn}(\mathrm{PPI})_{2}$ based deep-red OLEDs achieve maximum EQE of $13.1 \%$ with CIE coordinate of $(0.70,0.30)$. Highest luminance of $7261 \mathrm{~cd} \mathrm{~m}^{-2}$ is achieved. The device also shows very stable electroluminescent emission, peaking at $640 \mathrm{~nm}$ without significant change of CIE coordinate when increasing current density.

\section{Experimental}

\section{Material synthesis}

Ligand PPIH is synthesized according to literature. ${ }^{20}$ To further get zinc complex, $600 \mathrm{mg}$ (1.55 mmol) PPIH is dissolved in
$300 \mathrm{ml}$ ethanol under $60{ }^{\circ} \mathrm{C} .660 \mathrm{mg}(6.52 \mathrm{mmol})$ trimethylamine is added, followed by adding $\mathrm{Zn}(\mathrm{OAc})_{2} \cdot 2 \mathrm{H}_{2} \mathrm{O}(171 \mathrm{mg}$, $0.779 \mathrm{mmol})$. The mixture is stirred by magnetic stirring bar for $3 \mathrm{~h}$ before cooling down to room temperature. White crystal is found at the bottom of flask overnight. The product $\mathrm{Zn}(\mathrm{PPI})_{2}$ is filtered 3 days later and washed by ethanol. $1 \mathrm{H}$ NMR $(400 \mathrm{MHz}$, [D6]DMSO): $\delta=8.90(\mathrm{~d}, 2 \mathrm{H}, J=8.4 \mathrm{~Hz}), 8.06(\mathrm{~d}, 2 \mathrm{H}, J=7.8 \mathrm{~Hz})$, $7.97(\mathrm{~d}, 2 \mathrm{H}, J=8.4 \mathrm{~Hz}), 7.85-7.67(\mathrm{~m}, 10 \mathrm{H}), 7.52(\mathrm{t}, 2 \mathrm{H}, J=$ $7.8 \mathrm{~Hz}), 7.34-7.15(\mathrm{~m}, 4 \mathrm{H}), 7.13(\mathrm{t}, 2 \mathrm{H}, J=7.8 \mathrm{~Hz}), 6.93(\mathrm{t}, 2 \mathrm{H}, J=$ $8.1 \mathrm{~Hz}), 6.88(\mathrm{~d}, 2 \mathrm{H}, J=7.8 \mathrm{~Hz}), 6.79(\mathrm{t}, 4 \mathrm{H}, J=9 \mathrm{~Hz}), 6.27(\mathrm{t}, 2 \mathrm{H}$, $J=7.5 \mathrm{~Hz})$.

\section{OLEDs fabrication}

Zinc complex host material is purified twice by sublimation before device fabrication. Substrates with pre-patterned ITO are cleaned with acetone, ethanol and de-ionized water by ultrasonic bath for $10 \mathrm{~min}$ in each step. The substrates are then dried by dry nitrogen gas flow and oven at $120^{\circ} \mathrm{C}$. The devices with $\operatorname{Ir}(\mathrm{piq})_{3}$ are fabricated in vacuum chambers under $5 \times 10^{-4} \mathrm{~Pa}$. For device with emitter Ir(piq) ${ }_{3}$, the configuration is: $\mathrm{ITO} / \mathrm{MoO}_{3}$ $(10 \mathrm{~nm}) / \mathrm{NPB}(x \mathrm{~nm}) / \mathrm{TCTA}(5 \mathrm{~nm}) / \mathrm{Zn}(\mathrm{PPI})_{2}: 8 \mathrm{wt} \% . \operatorname{Ir}(\mathrm{piq})_{3}(30$ $\mathrm{nm}) / \mathrm{TPBi}(y \mathrm{~nm}) / \mathrm{LiF}(1 \mathrm{~nm}) / \mathrm{Al}$. For emitter $\operatorname{Ir}(\mathrm{pmiq})_{2}(\mathrm{acac})$, device structure is $\mathrm{ITO} / \mathrm{MoO}_{3}(8 \mathrm{~nm}) / \mathrm{TAPC}(120 \mathrm{~nm}) / \mathrm{TCTA}$ $(5 \mathrm{~nm}) / \mathrm{Zn}(\mathrm{PPI})_{2}: 1 \mathrm{wt} \% \operatorname{Ir}(\mathrm{pmiq})_{2}(\mathrm{acac})(40 \mathrm{~nm}) / \mathrm{TPBi}(5 \mathrm{~nm}) /$ Bphen $(80 \mathrm{~nm}) / \mathrm{LiF}(1 \mathrm{~nm}) / \mathrm{Al}$. Oxygen plasma treated $(5 \mathrm{~min})$ indium tin oxide (ITO) is used as anode, molybdenum oxide $\left(\mathrm{MoO}_{3}\right)$ is used as hole injection layer, 1,1-bis[(di-4-tolylamino) phenyl]cyclohexane (TAPC) and $N, N$-di(naphthalen-1-yl)- $N, N$ diphenyl-benzidine (NPB) as hole transport layer, 4,4,4tris(carbazol-9-yl)-triphenylamine (TCTA) and 2,2,2-(1,3,5-phenylen)-tris(1-phenyl-1 $H$-benzimidazol) (TPBi) as exciton blocking layer, $\mathrm{Zn}(\mathrm{PPI})_{2}$ doped with $\operatorname{Ir}(\mathrm{piq})_{3}$ or $\operatorname{Ir}(\mathrm{pmiq})_{2}(\mathrm{acac})$ as emission layer, TPBi and 4,7-diphenyl-1,10-phenanthroline (BPhen) as electron transport layer. Lithium fluoride (LiF) is used as electron injection layer and $100 \mathrm{~nm}$ aluminum as top electrode. Pixel size is $0.3 \mathrm{~mm}$ by $0.3 \mathrm{~mm}$.

\section{Measurement}

PL spectra are recorded by Edinburgh instruments (FLS 920 spectrometers) and UV-Vis absorption spectrum is measured by Shimadzu UV-Vis-NIR Spectrophotometer (UV-3600). ${ }^{1} \mathrm{H}$ nuclear magnetic resonance (NMR) measurements was carried out with Bruker $400 \mathrm{MHz}$ DRX spectrometer. All the devices are characterized immediately after fabrication in ambient environment without further encapsulation. Luminance, EL spectra and CIE coordinate information are measured by a PHOTO RESEARCH SpectraScan PR655 photometer and KEITHLEY 2400 SourceMeter as current source. The EL spectra and CIE coordinate, as well as luminance are recorded at each measurement step.

\section{Results and discussion}

$\mathrm{Zn}(\mathbf{P P I})_{2}$

The synthetic route to zinc complex material is shown in Scheme 1. This zinc complex is obtained by utilizing 


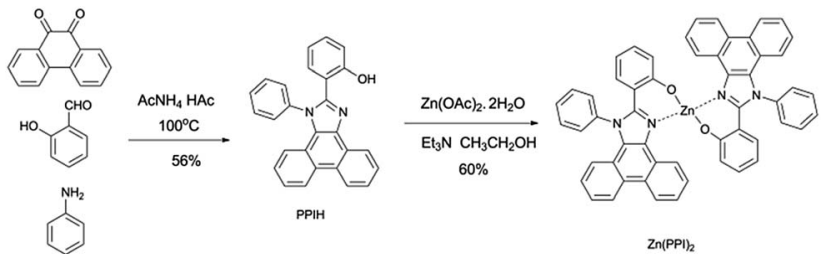

Scheme 1 Synthetic route for $\mathrm{Zn}(\mathrm{PPI})_{2}$.

trimethylamine with ethanol as solvent, since trimethylamine has better solubility than inorganic base. The yield is $60 \%$, which is higher than previous reported method. ${ }^{20}$ The main reason for the increase of product yield is ligand PPIH and trimethylamine have slightly better solubility in ethanol than PPIH and inorganic base in methanol.

Fig. 1 shows the physical properties including UV-Vis absorption and PL spectrum of $\mathrm{Zn}(\mathrm{PPI})_{2}$. Fig. 1 is the normalized UV-Vis absorption spectrum for $\mathrm{Zn}(\mathrm{PPI})_{2}$ and PL spectra for both $\mathrm{Zn}(\mathrm{PPI})_{2}$ and ligand PPIH. The spectra are recorded with a solution of these compounds about $10^{-5} \mathrm{mmol} \mathrm{L}^{-1}$ in $\mathrm{CH}_{2} \mathrm{Cl}_{2}$ at room temperature. For absorption spectrum, main peak at around $260 \mathrm{~nm}$ can be assigned to the $\pi \rightarrow \pi^{*}$ transition of the benzene ring. Weak absorption band is found from 300 to $400 \mathrm{~nm}$ with two weaker peaks. This can attribute to the delocalized $\pi \rightarrow \pi^{*}$ transition from ligand part in which the 2substituted phenolate to the $N$-phenyl phenanthroimidazole ring. ${ }^{20}$ For zinc complex at room temperature, the PL spectrum covers wide range from $380 \mathrm{~nm}$ to $550 \mathrm{~nm}$ with a peak at $429 \mathrm{~nm}$. However, ligand PPIH gives PL spectrum with peak at $467 \mathrm{~nm}$.

\section{Deep-red OLED devices based on $\mathrm{Zn}(\mathrm{PPI})_{2}$}

Fig. 2 shows the energy diagram for deep-red PhOLEDs, both for device with emitter $\operatorname{Ir}(\text { piq })_{3}$ and $\operatorname{Ir}(\text { pmiq })_{2}($ acac). The energy level data is collected from literatures. ${ }^{20,22,23}$ We firstly investigate deep-red OLEDs with $\operatorname{Ir}(\text { piq })_{3}$ as guest material. HOMO

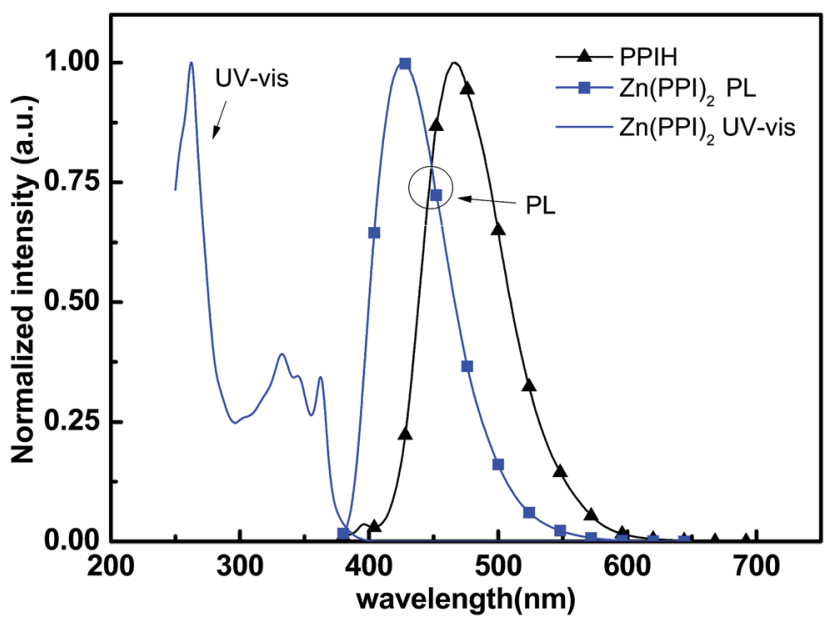

Fig. 1 Normalized UV-Vis absorption and photoluminescence spectra for PPIH and $\mathrm{Zn}(\mathrm{PPI})_{2}$.
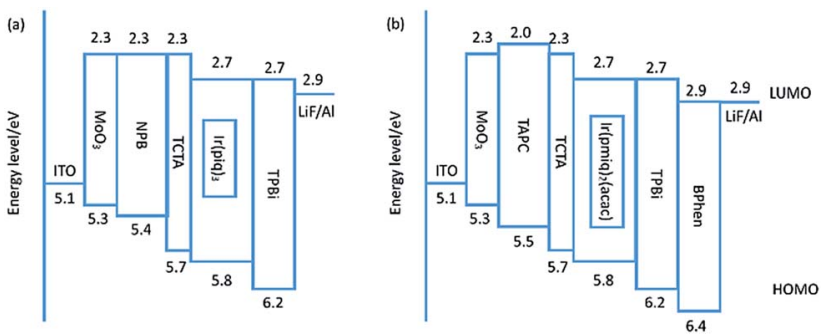

Fig. 2 Energy diagram for deep-red OLEDs based on $\mathrm{Zn}(\mathrm{PPI})_{2}$.

level of $\mathrm{Zn}(\mathrm{PPI})_{2}$ is located at $5.8 \mathrm{eV}$ and LUMO level at $2.7 \mathrm{eV}$, finely confining the energy gap of dopant $\operatorname{Ir}(\mathrm{piq})_{3}$. The triplet energy level of host is $2.67 \mathrm{eV}$, which is higher than dopant $\operatorname{Ir}(\text { piq })_{3}$ at $2.05 \mathrm{eV},{ }^{23}$ so triplet energy can transfer from host to guest. Devices are fabricated with the configuration of: ITO/ $\mathrm{MoO}_{3}(10 \mathrm{~nm}) / \mathrm{NPB}(x \mathrm{~nm}) / \mathrm{TCTA}(5 \mathrm{~nm}) / \mathrm{Zn}(\mathrm{PPI})_{2}: 8 \mathrm{wt} \%$. $\operatorname{Ir}(\mathrm{piq})_{3}(30 \mathrm{~nm}) / \mathrm{TPBi}(y \mathrm{~nm}) / \mathrm{LiF}(1 \mathrm{~nm}) / \mathrm{Al}$. Here, the thicknesses of NPB and TPBi are slightly optimized to obtain optimized device performance and to investigate the influence of current injection on EL spectra stability.

Fig. 3 shows PhOLEDs device performance based on $\mathrm{Zn}(\mathrm{PPI})_{2}$ and $\operatorname{Ir}(\mathrm{piq})_{3}$, with variation of NPB $(x \mathrm{~nm})$ and TPBi $(y \mathrm{~nm})$ thickness. NPB thickness is changed from $50 \mathrm{~nm}$ to $60 \mathrm{~nm}$ and $70 \mathrm{~nm}$, while TPBi is varied between $30 \mathrm{~nm}$ and $40 \mathrm{~nm}$, to slightly change the injection and keep recombination zone within the emission layer. ${ }^{20}$ Fig. 3(a) exhibits the relation between driving voltages and current density for these devices. The current density changes slightly when optimizing hole and electron transport layers' thickness. For device with $50 \mathrm{~nm} \mathrm{NPB}$ $(x=50 \mathrm{~nm})$ and $30 \mathrm{~nm}$ TPBi $(y=30 \mathrm{~nm})$, it gives highest current density under the same driving voltage among all devices. When increasing thickness of either NPB or TPBi, devices show lower current density. This could result from the resistance of organic
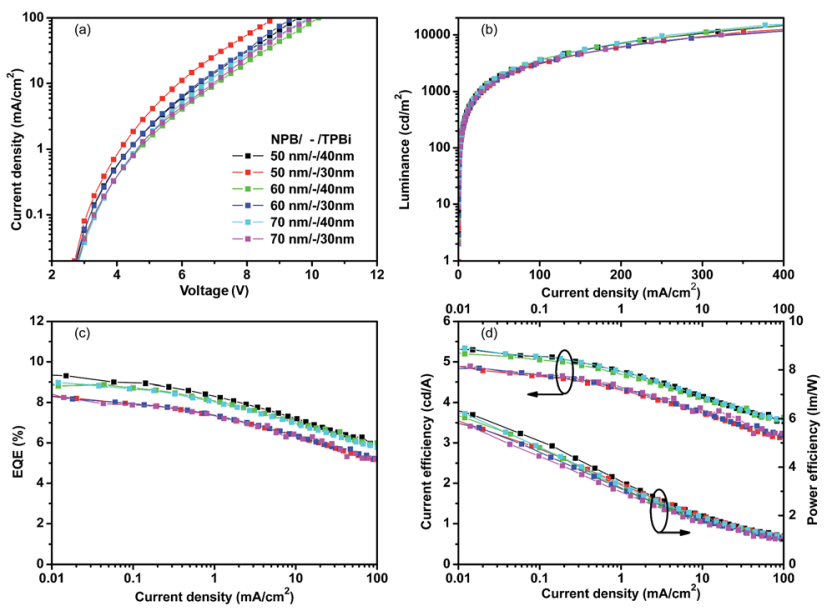

Fig. $3 \quad \operatorname{Ir}(\mathrm{piq})_{3}$ based devices performance with varied hole and electron transport layer (NPB and TPBi) thickness. (a) Voltage-current density curve, (b) current-luminance curve, (c) current densityexternal quantum efficiency (EQE) curve, (d) current density-current efficiency and power efficiency curve. 
layer. ${ }^{24}$ When NPB and TPBi are used as non-doped hole and electron transport layer, increasing transport layer thickness rises up device resistance and hinder the charge transport, which leads to lower current density. ${ }^{25}$

Fig. 3(b) shows the luminance behavior under different current densities for devices based on $\mathrm{Zn}(\mathrm{PPI})_{2}$ and $\operatorname{Ir}(\mathrm{piq})_{3}$. For all devices, maximum luminance is higher than $10000 \mathrm{~cd} \mathrm{~m}^{-2}$. These devices give similar current density and luminance curves. For device with $50 \mathrm{~nm} \mathrm{NPB}(x=50 \mathrm{~nm})$ and $40 \mathrm{~nm}$ TPBi $(y=40 \mathrm{~nm}$ ), the turn-on voltage (voltage for luminance at $1 \mathrm{~cd} \mathrm{~m}^{-2}$ ) is $2.7 \mathrm{~V}$. The device reaches $100 \mathrm{~cd} \mathrm{~m}^{-2}$ under very low current density about $2.5 \mathrm{~mA} \mathrm{~cm}^{-2}$ and $1000 \mathrm{~cd} \mathrm{~m} \mathrm{~m}^{-2}$ at $26 \mathrm{~mA} \mathrm{~cm}^{-2}$. The luminance further increases to $10000 \mathrm{~cd} \mathrm{~m}^{-2}$ when the current density is about $300 \mathrm{~mA} \mathrm{~cm}{ }^{-2}$. Maximum luminance about $20000 \mathrm{~cd} \mathrm{~m}^{-2}$ can be obtained at $400 \mathrm{~mA}$ $\mathrm{cm}^{-2}$ before catastrophic device failure.

The thickness of charge transport layer plays an important role on charge injection balance and recombination zone location, therefore it could influence device efficiency and color stability under high current density. ${ }^{6}$ In Fig. 3(c) and (d), we notice that under the same current density, devices with $50 \mathrm{~nm}$ NPB $(x=50 \mathrm{~nm})$ and $40 \mathrm{~nm}$ TPBi $(y=40 \mathrm{~nm})$ gives highest external quantum efficiency (EQE) and highest current efficiency. While for devices with $70 \mathrm{~nm} \operatorname{NPB}(x=70 \mathrm{~nm})$ and $30 \mathrm{~nm}$ TPBi $(y=30 \mathrm{~nm})$, lowest EQE or current efficiency is obtained, because of unbalanced charge injection. Highest EQE of $9.5 \%$ is obtained by $50 \mathrm{~nm} \mathrm{NPB}(x=50 \mathrm{~nm})$ and $40 \mathrm{~nm}$ TPBi $(y=40 \mathrm{~nm})$, devices, with current efficiency of $5.35 \mathrm{~cd} \mathrm{~A}^{-1}$ and power efficiency of $6.21 \mathrm{l} \mathrm{m} \mathrm{W} \mathrm{W}^{-1}$. This could attribute to balanced charge recombination and well confinement of excitons within emission layer. The EQE is rolling down when increasing current density, which may result from triplet-triplet annihilation and triplet-polaron quenching. ${ }^{26}$

Fig. 4 summarizes the typical EL spectra for devices with $\operatorname{Ir}(\text { piq })_{3}$ under current density from $0.1 \mathrm{~mA} \mathrm{~cm}^{-2}$ to $100 \mathrm{~mA} \mathrm{~cm}^{-2}$. Fig. 4(a) shows EL spectra of device with $50 \mathrm{~nm} \mathrm{NPB}(x=50 \mathrm{~nm})$ and $40 \mathrm{~nm}$ TPBi $(y=40 \mathrm{~nm})$, which gives the best device efficiency. Fig. 4(b) illustrates EL spectra of device with $50 \mathrm{~nm}$ NPB $(x=50 \mathrm{~nm})$ and $30 \mathrm{~nm}$ TPBi $(y=40 \mathrm{~nm})$, which has lowest injection resistance. All these EL spectra peak at $636 \mathrm{~nm}$, with full width at half maximum (FWHM) about $100 \mathrm{~nm}$. The CIE coordinates are $(0.68,0.32)$ for current density from

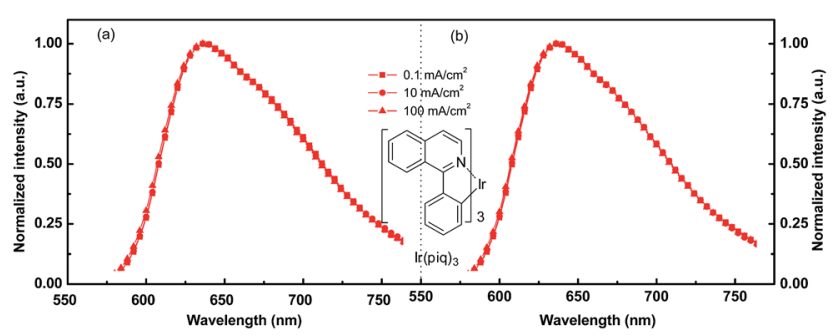

Fig. 4 Electroluminescent spectra of deep-red OLEDs with $\operatorname{Ir}(\text { piq })_{3}$ emitter under different current density. (a) Balanced device with $50 \mathrm{~nm}$ NPB $(x=50 \mathrm{~nm})$ and $40 \mathrm{~nm}$ TPBi $(y=40 \mathrm{~nm})$, with best device efficiency, (b) unbalanced device with $50 \mathrm{~nm} \mathrm{NPB} \mathrm{(} x=50 \mathrm{~nm}$ ) and $30 \mathrm{~nm}$ TPBi $(y=30 \mathrm{~nm})$, with lowest charge injection resistance.
$0.1 \mathrm{~mA} \mathrm{~cm}^{-2}$ to $100 \mathrm{~mA} \mathrm{~cm}^{-2}$. In this range, the CIE coordinate shifts smaller than 0.005. Fig. 4(a) indicates the device with balanced charge injection and fine exciton confinement configuration can exhibit extremely stable EL spectra even under high driving current density of $100 \mathrm{~mA} \mathrm{~cm}^{-2}$. Meanwhile, Fig. 4(b) indicates that even electron and hole is slightly unbalanced, no observable EL spectra change is found with increased driving voltage and a very small change of CIE coordinates.

Based on the investigation on $\operatorname{Ir}(\text { piq })_{3}$ emitter, we further study the performance of deep-red devices with $\operatorname{Ir}(\mathrm{pmiq})_{2}$ (acac). ${ }^{22}$ Fig. 5(a) shows the devices' voltage-current densityluminance curves. The turn-on voltage is $3.7 \mathrm{~V}$ and device can reach maximum luminance of $7262 \mathrm{~cd} \mathrm{~m}^{-2}$ under $18.5 \mathrm{~V}$ before device failure. Higher turn-on voltage compared to $\operatorname{Ir}($ piq) 3 based device can attribute to thicker device layers. As we can see from Fig. 5(b), the maximum EQE of $13.1 \%$ is achieved. EQE rolls down a little to about $10 \%$ at $80-100 \mathrm{~mA} \mathrm{~cm}^{-2}$, which is a small roll-off compared with the same guest material doped in other host materials. ${ }^{22}$ The maximum current efficiency is $6.8 \mathrm{~cd} \mathrm{~A}^{-1}$ and the maximum power efficiency is $5.41 \mathrm{~m} \mathrm{~W}^{-1}$. The EL spectra stability is showed in Fig. 5(d). As we can see, there is no significant shift for EL spectra with peak at $640 \mathrm{~nm}$. The CIE coordinate is $(0.70,0.30)$ and the change of CIE coordinate is smaller than 0.004 from $0.1 \mathrm{~mA} \mathrm{~cm}^{-2}$ to $100 \mathrm{~mA} \mathrm{~cm}^{-2}$. Deep-red device based on $\mathrm{Zn}(\mathrm{PPI})_{2}$ and $\operatorname{Ir}(\mathrm{pmiq})_{2}$ (acac) also shows very stable EL spectra stability and slightly higher EQE than device based on $\operatorname{Ir}(\text { piq })_{3}$.

Good efficiency and stable EL property for these deep-red device are the results of these possible reasons: (1) the bipolar property of this $\mathrm{Zn}(\mathrm{PPI})_{2}$ host material facilitates the charge balance within the device; (2) with the blocking layer, the emission zone is well confined within the emission layer even under high current density. ${ }^{20}$ Possible reasons attribute to EQE difference for $\operatorname{Ir}(\mathrm{mpiq})_{2}$ (acac) and $\operatorname{Ir}(\mathrm{piq})_{3}$ based device could be difference of device configuration, intrinsic quantum
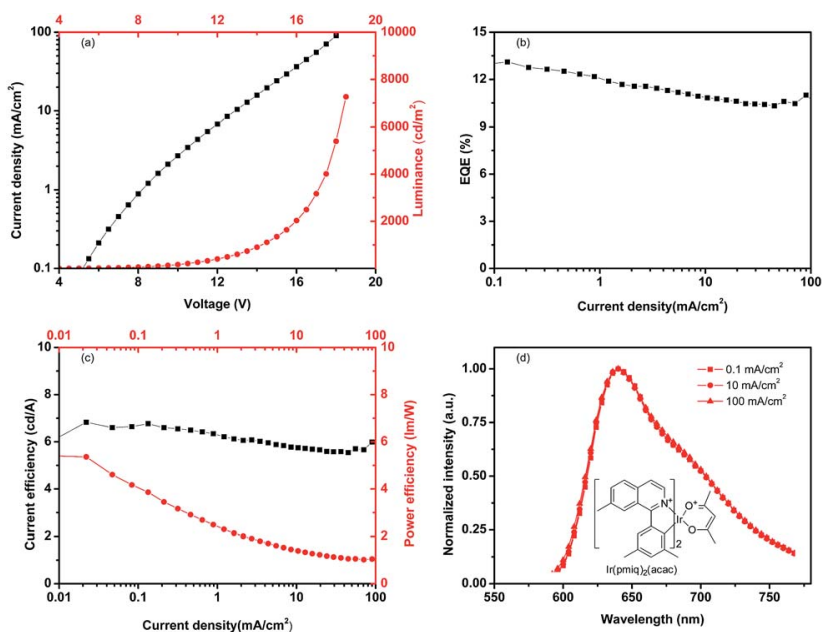

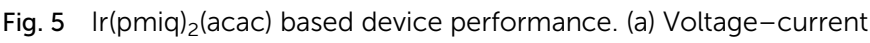
density-luminance curve, (b) current density-external quantum efficiency (EQE) curve, (c) current density-current efficiency and power efficiency curve, (d) EL spectra under different current density. 
efficiency $^{27}$ or dipole orientation..$^{28}$ For deep-red OLEDs, two reasons can attribute to lower efficiency compared to blue, green, orange-red OLEDs: firstly, the nonradiative decay rate of emitter increases when the energy gap is decreasing according to energy gap law; ${ }^{29}$ secondly, a drop of luminous flux within the deep-red region and decrease of eye sensitivity among this wavelength range, leads to lower power efficiency compared to green or blue OLEDs. ${ }^{30}$ Compared to reported results, ${ }^{15,17,18}$ our devices show good performance among deep-red OLEDs, with stable CIE coordinate as high as $(0.70,0.30)$ even at high current density.

\section{Conclusions}

In conclusion, zinc complex host material named $\mathrm{Zn}(\mathrm{PPI})_{2}$ is synthesized by an improved strategy, with slightly higher product yield of $60 \%$ by two steps and easy purification. Deepred PhOLEDs are fabricated based on host $\mathrm{Zn}(\mathrm{PPI})_{2}$ and dopant $\operatorname{Ir}(\text { piq) })_{3}$ and $\operatorname{Ir}(\text { pmiq) })_{2}$ (acac). Highest EQE of $9.5 \%$ is obtained for $\operatorname{Ir}(\text { piq) })_{3}$ based device and $13.1 \%$ for $\operatorname{Ir}(\text { pmiq })_{2}($ acac $)$ device. These devices show deep red emission with CIE $x$ of 0.67 for $\operatorname{Ir}(\text { piq })_{3}$ and 0.70 for $\operatorname{Ir}(\text { pmiq })_{2}$ (acac) emitter. Devices with host $\mathrm{Zn}(\mathrm{PPI})_{2}$ and dopant $\operatorname{Ir}(\text { piq })_{3}$ and $\operatorname{Ir}(\text { pmiq })_{2}$ (acac) exhibit very stable electroluminescent spectra and barely CIE coordinates shift when increasing current density. The results will provide a clue towards further development of efficient and stable deep-red OLEDs.

\section{Conflicts of interest}

There are no conflicts to declare.

\section{Acknowledgements}

This work was supported by the National Natural Science Foundation of China (Grant No. 21574049) and the National High Technology Research and Development Program of China (863 program, No. 2015AA033404).The authors thank for Dr Zaifei Ma, Dr Simone Lenk and Yuan Liu for beneficial discussion in Dresden Integrated Center for Applied Physics and Photonic Materials (IAPP) at TU Dresden. We also thank the HUST Analytical and Testing Center for material characterization and related measurements.

\section{References}

1 C. W. Tang and S. A. Vanslyke, Organic electroluminescent diodes, Appl. Phys. Lett., 1987, 51, 913-915.

2 C. Adachi, M. A. Baldo, M. E. Thompson and S. R. Forrest, Nearly $100 \%$ internal phosphorescence efficiency in an organic light-emitting device, J. Appl. Phys., 2001, 90, 50485051.

3 M. A. Baldo, D. F. O'Brien, Y. You, A. Shoustikov, S. Sibley, M. E. Thompson, et al., Highly efficient phosphorescent emission from organic electroluminescent devices, Nature, 1998, 395, 151-154.
$4 \mathrm{H}$. Kaji, et al., Purely organic electroluminescent material realizing $100 \%$ conversion from electricity to light, Nat. Commun., 2015, 6, 8476.

5 H. Uoyama, K. Goushi, K. Shizu, H. Nomura and C. Adachi, Highly efficient organic light-emitting diodes from delayed fluorescence, Nature, 2012, 492, 234-238.

6 K. Walzer, B. Maennig, M. Pfeiffer and K. Leo, Highly efficient organic devices based on electrically doped transport layers, Chem. Rev., 2007, 107, 1233-1271.

7 M. Ikai, S. Tokito, Y. Sakamoto, T. Suzuki and Y. Taga, Highly efficient phosphorescence from organic light-emitting devices with an exciton-block layer, Appl. Phys. Lett., 2001, 79, 156-158.

8 M. C. Gather and S. Reineke, Recent advances in light outcoupling from white organic light-emitting diodes, $J$. Photonics Energy, 2015, 5, 057607.

9 S. Reineke, F. Lindner, G. Schwartz, N. Seidler, K. Walzer, B. Lussem, et al., White organic light-emitting diodes with fluorescent tube efficiency, Nature, 2009, 459, 234-238.

10 C. L. Ho, H. Li and W. Y. Wong, Red to near-infrared organometallic phosphorescent dyes for OLED applications, J. Organomet. Chem., 2014, 751, 261-285.

11 J. C. G. Bünzli and S. V. Eliseeva, Lanthanide NIR luminescence for telecommunications, bioanalyses and solar energy conversion, J. Rare Earths, 2010, 28, 824-842.

12 A. Rogalski and K. Chrzanowski, Infrared devices and techniques (revision), Metrology and Measurement Systems, 2014, 21, 565-618.

13 D. H. Kim, N. S. Cho, H.-Y. Oh, J. H. Yang, W. S. Jeon, J. S. Park, et al., Highly Efficient Red Phosphorescent Dopants in Organic Light-Emitting Devices, Adv. Mater., 2011, 23, 2721-2726.

14 C. H. Fan, P. Sun, T. H. Su and C. H. Cheng, Host and dopant materials for idealized deep-red organic electrophosphorescence devices, Adv. Mater., 2011, 23, 2981-2985.

15 H. Fujii, H. Sakurai, K. Tani, K. Wakisaka and T. Hirao, Bright and ultimately pure red electrophosphorescent diode bearing diphenylquinoxaline, IEICE Electronics Express, 2005, 2, 260-266.

16 J. H. Jou, Y. T. Su, M. T. Hsiao, H. H. Yu, Z. K. He, S. C. Fu, et al., Solution-Process-Feasible Deep-Red Phosphorescent Emitter, J. Phys. Chem. C, 2016, 120, 18794-18802.

17 S. Wang, X. Yan, Z. Cheng, H. Zhang, Y. Liu and Y. Wang, Highly Efficient Near-Infrared Delayed Fluorescence Organic Light Emitting Diodes Using a PhenanthreneBased Charge-Transfer Compound, Angew. Chem., Int. Ed., 2015, 54, 13068-13072.

18 Y. Nagai, H. Sasabe, J. Takahashi, N. Onuma, T. Ito, S. Ohisa, et al., Highly efficient, deep-red organic light-emitting devices using energy transfer from exciplexes, J. Mater. Chem. C, 2017, 5, 527-530.

19 H. Kanno, K. Ishikawa, Y. Nishio, A. Endo, C. Adachi and K. Shibata, Highly efficient and stable red phosphorescent organic light-emitting device using bis[2-(2-benzothiazoyl) phenolato]zinc(II) as host material, Appl. Phys. Lett., 2007, 90, 1-4. 
20 K. Wang, F. Zhao, C. Wang, S. Chen, D. Chen, H. Zhang, et al., High-performance red, green, and blue electroluminescent devices based on blue emitters with small singlet-triplet splitting and ambipolar transport property, Adv. Funct. Mater., 2013, 23, 2672-2680.

21 C. S. Oh, C. W. Lee and J. Y. Lee, Simple heteroatom engineering for tuning the triplet energy of organometallic host materials for red, green and blue phosphorescent organic light-emitting diodes, Chem. Commun., 2013, 49, 3875-3877.

22 Y. Li, W. Zhang, L. Zhang, X. Wen, Y. Yin, S. Liu, et al., Ultrahigh general and special color rendering index white organic light-emitting device based on a deep red phosphorescent dye, Org. Electron., 2013, 14, 3201-3205.

23 A. Tsuboyama, H. Iwawaki, M. Furugori, T. Mukaide, J. Kamatani, S. Igawa, et al., Homoleptic Cyclometalated Iridium Complexes with Highly Efficient Red Phosphorescence and Application to Organic LightEmitting Diode, J. Am. Chem. Soc., 2003, 125, 12971-12979.

24 J. Blochwitz, M. Pfeiffer, T. Fritz and K. Leo, Low voltage organic light emitting diodes featuring doped phthalocyanine as hole transport material, Appl. Phys. Lett., 1998, 73, 729-731.
25 R. Meerheim, B. Luessem and K. Leo, Efficiency and Stability of p-i-n Type Organic Light Emitting Diodes for Display and Lighting Applications, Proc. IEEE, 2009, 97, 1606-1626.

26 S. Reineke, K. Walzer and K. Leo, Triplet-exciton quenching in organic phosphorescent light-emitting diodes with Irbased emitters, Phys. Rev. B: Condens. Matter Mater. Phys., 2007, 75, 1-13.

27 M. Furno, R. Meerheim, S. Hofmann, B. Lüssem and K. Leo, Efficiency and rate of spontaneous emission in organic electroluminescent devices, Phys. Rev. B: Condens. Matter Mater. Phys., 2012, 85, 1-21.

28 M. J. Jurow, C. Mayr, T. D. Schmidt, T. Lampe, P. I. Djurovich, W. Brütting, et al., Understanding and predicting the orientation of heteroleptic phosphors in organic light-emitting materials, Nat. Mater., 2016, 15, 8591.

29 J. V. Caspar and T. J. Meyer, Application of the Energy Gap Law to Excited-State Decay, J. Phys. Chem., 1983, 87, 952-957.

$30 \mathrm{~S}$. R. Forrest, D. D. C. Bradley and M. E. Thompson, Measuring the efficiency of organic light-emitting devices, Adv. Mater., 2003, 15, 1043-1048. 